\title{
Geographical heterogeneity and socio-ecological risk profiles of dengue in Jakarta, Indonesia
}

\author{
Heni Prasetyowati, ${ }^{1}$ Pandji Wibawa Dhewantara, ${ }^{2}$ Joni Hendri, ${ }^{1}$ Endang Puji Astuti, ${ }^{1}$ \\ Yalemzewod Assefa Gelaw, ${ }^{3,4}$ Harapan Harapan, ${ }^{5-7}$ Mara Ipa, ${ }^{1}$ Widyastuti Widyastuti, ${ }^{8}$ \\ Dwi Oktavia Tatri Lestari Handayani, ${ }^{8}$ Ngabila Salama, ${ }^{8}$ Mirsal Picasso ${ }^{8}$ \\ ${ }^{1}$ Pangandaran Unit for Health Research and Development, National Institute of Health Research and \\ Development (NIHRD), Ministry of Health of Indonesia, Pangandaran, Indonesia; ${ }^{2}$ Center for Research and \\ Development of Public Health Effort, National Institute of Health Research and Development (NIHRD), \\ Ministry of Health of Indonesia, Jakarta, Indonesia; ${ }^{3}$ Population Child Health Research Group, School of \\ Women's \& Children's Health, UNSW, NSW Australia; ${ }^{4}$ Institute of Public Health, College of Medicine and \\ Health Science, University of Gondar, Gondar, Ethiopia; ${ }^{5}$ Medical Research Unit, School of Medicine, Syiah \\ Kuala University, Banda Aceh, Aceh, Indonesia; ${ }^{6}$ Tropical Disease Centre, School of Medicine, Syiah Kuala \\ University, Banda Aceh, Aceh, Indonesia; ${ }^{7}$ Department of Microbiology, School of Medicine, Syiah Kuala \\ University, Banda Aceh, Aceh, Indonesia; ${ }^{8}$ Jakarta Provincial Health Office, Jakarta, Indonesia
}

\begin{abstract}
The aim of this study was to assess the role of climate variability on the incidence of dengue fever (DF), an endemic arboviral infection existing in Jakarta, Indonesia. The work carried out
\end{abstract}

Correspondence: Pandji Wibawa Dhewantara, Center for Research and
Development of Public Health Effort, National Institute of Health
Research and Development (NIHRD), Ministry of Health of Indonesia,
Jakarta, 10560, Indonesia.
E-mail: p.dhewantara@gmail.com

Key words: Dengue; spatial analysis; cluster detection; climate; risk profile; Indonesia.

Acknowledgements: the authors would like to thank head of the Provincial Health Office (DHO) of Jakarta in providing the data.

Ethical approval: this study was reviewed and approved by the Ethics Committee for Health Research, National Institute of Health Research and Development, Ministry of Health of Indonesia (No. LB.02.01/2/KE.232/2018). All the data for the individuals were kept confidential as requested.

See online Appendix for additional Tables and Figures.

Received for publication: 26 September 2020.

Revision received: 25 January 2021.

Accepted for publication: 26 January 2021.

(C) Copyright: the Author(s), 2021

Licensee PAGEPress, Italy

Geospatial Health 2021; 16:948

doi:10.4081/gh.2021.948

This article is distributed under the terms of the Creative Commons Attribution Noncommercial License (CC BY-NC 4.0) which permits any noncommercial use, distribution, and reproduction in any medium, provided the original author(s) and source are credited. included analysis of the spatial distribution of confirmed DF cases from January 2007 to December 2018 characterising the sociodemographical and ecological factors in DF high-risk areas. Spearman's rank correlation was used to examine the relationship between DF incidence and climatic factors. Spatial clustering and hotspots of DF were examined using global Moran's I statistic and the local indicator for spatial association analysis. Classification and regression tree (CART) analysis was performed to compare and identify demographical and socio-ecological characteristics of the identified hotspots and low-risk clusters. The seasonality of DF incidence was correlated with precipitation $(r=0.254, \mathrm{P}<0.01)$, humidity $(r=0.340, \mathrm{P}<0.01)$, dipole mode index $(r=-0.459$, $\mathrm{P}<0.01)$ and $\mathrm{T}_{\text {min }}(r=-0.181, \mathrm{P}<0.05)$. DF incidence was spatially clustered at the village level $(I=0.294, \mathrm{P}<0.001)$ and 22 hotspots were identified with a concentration in the central and eastern parts of Jakarta. CART analysis showed that age and occupation were the most important factors explaining DF clustering. Areaspecific and population-targeted interventions are needed to improve the situation among those living in the identified DF high-risk areas in Jakarta.

\section{Introduction}

Dengue fever (DF) is a common vector-borne infectious disease transmitted by Aedes aegypti and Ae. albopictus. More than 390 million cases were reported annually (Bhatt et al., 2013), and approximately USD 8.9 billion lost due to these infections worldwide (Shepard et al., 2016). According to the World Health Organization (WHO) more than 2.5 billion people are at high risk, with at least $70 \%$ of whom at risk residing in Southeast Asia and the Western Pacific region (WHO, 2011). Indonesia is one of the tropical countries where DF is a common viral infection (Harapan et al., 2019a). All four dengue serotypes (DEN-1 to 4) are currently circulating in the country emphasizing a great risk of infection and public health burden (Karyanti et al., 2014).

The first DF case in Indonesia was reported in Jakarta and Surabaya in 1968 (Sumarmo, 1987). To date, DF outbreaks have 
been reported in all 34 provinces and 514 districts across the nation, including the capital city, Jakarta, known as the most populated city in Indonesia with a high incidence of DF each year. The number of DF cases has increased from 36,345 in 2007 to 49,496 in 2016, while there was a decrease to 9204 in 2018 (Ministry of Health, Republic of Indonesia, 2018). A recent study demonstrates that all four dengue serotypes have been identified in the city, which may have led to imported cases also in other countries (Lestari et al., 2017; Harapan et al., 2019a). To date, a tetravalent dengue vaccine has been developed and advanced to clinical trial (Biswal et al., 2019). However, so far, DF control is primarily focusing on vector control aimed at larviciding and reduction of breeding sites (Karyanti et al., 2014; Hamid et al., 2017). Despite its importance, information on the variation in the distribution of risk of DF and socio-ecological characteristics affecting its transmission spatially and temporally at the village level within the area covered by Jakarta are lacking. Such information is essential as it would provide evidence for allowing better intervention strategies in supporting existing DF control efforts.

A large number of factors may affect the variation in DF incidence at finer scales, e.g., heterogeneity of socio-ecological factors, such as mobility, access to water and sanitation and socioeconomic status (Schmidt et al., 2011; Li et al., 2018; Chen et al., 2019; Harapan et al., 2019b). In addition, climatic factors have been known to have a strong effect on the distribution DF transmission (Astuti et al., 2019; Xu et al., 2019). Precipitation may have either a positive or negative effect by rainfall producing water bodies in the environment thus facilitates an increased number of breeding sites for Aedes mosquitoes. Yet, extreme rainfall and flooding could flush and diminish the immature mosquitoes and their breeding sites (Seidahmed \& Eltahir, 2016). Further, humidity together with temperature within suitable margins contribute to mosquito breeding and taken together, all these variables play an important function on mosquito survival and their ability to host and transmit the dengue virus (Morin et al., 2013; Gimenez et al., 2020).

Geographical information systems (GIS) and spatial statistics are commonly used in the public health field (Oliveira et al., 2013; Fletcher-Lartey and Caprarelli, 2016; Diptyanusa et al., 2020) to help map and profile disease characteristics including potentially related environmental and socioeconomic features. Several studies have used GIS and spatial analysis for mapping and understanding the geographic pattern of dengue cases at the national (Xu et al., 2019; Zambrano et al., 2019) and local level (e.g., district or city level) (Carvalho et al., 2017; Fuentes-Vallejo, 2017; Astuti et al., 2019). Spatial analyses allow the identification of disease clusters, which can help reveal underlying risk factors of transmission in neighbouring areas. This can be useful in supporting epidemiological surveillance and in providing better visualization and generating hypotheses, which could facilitate more thorough control strategies (Fletcher-Lartey and Caprarelli, 2016).

The present study aimed to: i) examine the relationship between DF incidence and climate variability during the period 2007-2018; ii) identify spatial clusters with the highest risk of DF; and iii) attempt to profile socio-ecological characteristics of highrisk clusters of DF in Jakarta, since better information would help local health authorities to better design and implement dengue control strategies in the city of Jakarta.

\section{Materials and methods}

\section{Study site}

The study was carried on in the city of Jakarta, situated in the lowland area of north-western Java island. It covers an area of 622.33 $\mathrm{km}^{2}$ and comprises six municipalities, 44 sub-districts and 267 villages. Based on the 2010 census report, the population amounts to approximately 9.6 million with a density at the village level ranging from 2,423 to 18,761 people per $\mathrm{km}^{2}$. Jakarta has a tropical climate with a mean temperature of $28.7^{\circ} \mathrm{C}$ and the annual precipitation ranges from 1459 to $1600 \mathrm{~mm}$ with the highest rate in February.

\section{Data acquisition}

Confirmed DF cases for the period of January 2007 to December 2018 were obtained from the disease information system managed by the Jakarta Provincial Health Office (PHO). The data contain information on age, gender, date of hospital admission and address (village identification). In Indonesia, DF is classified as a notifiable disease since 1968. All health facilities are required to report all DF cases to the District Health Office (DHO) within 24 hours after diagnosis. Population data and population density $\left(\right.$ per $\left.\mathrm{km}^{2}\right)$ at the village level for each corresponding year were collected from the Bureau of Statistics.

The village-level socio-ecological data were extracted from village census ('Potensi Desa'). For each village, data for the number of households in slum, drinking water source, main occupation, number of doctors and doctor per 1000 people were collected. Additionally, road network density data $\left(\right.$ per $\mathrm{km}^{2}$ ) for each county were calculated based on road length divided by areal space. The road network density was used as a proxy for connectivity which reflects the movement of people, which is known to be a factor associated with dengue distribution in urban areas (Qi et al., 2015; Li et al., 2018). Monthly climate data, including the mean temperature $\left(\mathrm{T}_{\text {mean }}\right)$, the minimum temperature $\left(\mathrm{T}_{\text {min }}\right)$, the maximum temperature $\left(\mathrm{T}_{\text {max }}\right)$, the monthly average relative humidity $\left(\mathrm{RH}_{\text {avg }}\right)$, the mean precipitation $\left(\mathrm{P}_{\text {avg }}\right)$ for the study period, were obtained from the Meteorological, Climatological and Geophysical Bureau database (http://dataonline.bmkg.go.id/). Data on the monthly El Niño-Southern Oscillation (Niño3.4) a periodic variation in sea surface temperatures, and the dipole mode index (DMI), also known as the Indian Ocean Dipole (IOD) were obtained from the Earth System Research Laboratory of the National Oceanic and Atmospheric Administration (NOAA) (https://psl.noaa.gov/gcos wgsp/Timeseries/SOI/) in the US and from the Japan Agency for Marine-Earth Science and Technology (JAMSTEC) (http://www. jamstec.go.jp/aplinfo/sintexf/iod/dipole_mode_index.html), respectively.

\section{Data analysis}

\section{Approach to seasonal variation}

To explore seasonal patterns and trends with respect to dengue incidence, we expressed the weekly incidence of dengue (Yt) as trend $(\mathrm{Tt})$, cyclical component $(\mathrm{Ct})$, seasonal component $(\mathrm{St})$ and error or residual component (Et) by employing a multiplicative, seasonal decomposition analysis using SPSS version 21 (IBM Corp., Armonk, NY, USA). This analysis decomposes the timeseries to generate these components at time $t$ as described by Cleveland et al. (1990). 


\section{Relationship between dengue incidence and climate variability}

A Spearman's correlation test was performed to examine associations between monthly dengue incidence and monthly climatic variables including $\mathrm{T}_{\text {mean }}, \mathrm{T}_{\min }, \mathrm{T}_{\max }, \mathrm{RH}_{\text {avg }}, \mathrm{P}_{\text {avg }}$, Niño3.4 and DMI. A $95 \%$ confidence interval $(95 \% \mathrm{CI})$ was calculated and significance assessed at $\alpha=0.05$. Correlograms were made by using $R$ software ('Hmisc' package).

\section{Spatial analysis of the incidence of dengue}

The village was used as the geographic unit for the analysis $(n=261)$. We did not include villages in Kepulauan Seribu (Thousand Islands) in the study as the number of DF cases there were low. DF cases were linked with village IDs and polygons by using ArcGIS 10.5 [Environmental Systems Research Institute (ESRI), Redlands, CA, USA]. Village-level polygons (shapefile) were obtained from the Indonesian Statistical Services Information System of National Bureau of Statistics (Sistem Informasi Layanan Statistik) (https://www.bps.go.id/).

\section{Incidence mapping}

Crude incidence of dengue at village-level (per 10,000 people) was calculated and mapped. The village-level incidence maps of dengue were created by ArcGIS 10.5.1 (ESRI).

\section{Clustering assessment}

Spatial neighbourhood weight was created based on a Queenbased spatial contiguity matrix (where the village polygons share a common edge or vertex). Moran's $I$ analysis (Moran, 1950) was performed to estimate global spatial autocorrelation of the incidence of dengue during 2007-2018. Furthermore, local indicator spatial association analysis was performed to locate high-high $(\mathrm{HH})$ risk clusters, low-low (LL) risk cluster and outliers designated as high-low (HL) and low-high (LH) according to Anselin (1995). A HH cluster consists of villages with high rates adjacent to other such villages, while the LL cluster indicates the opposite villages with low rates close to other low-rate villages. All of the above spatial clustering analyses were performed using GeoDA v.1.8 software (https://geodacenter. github.io/download_linux. html).

\section{Profiling and comparisons}

Demographical and socio-ecological characteristics of $\mathrm{HH}$ and
LL clusters were profiled and compared. Independent t-test or Mann-Whitney U test (for continuous variables) and Fischer's Exact/Chi-square (for categorical variables) were performed. Levels of significance were set at 5\%. Statistical analysis was performed using SPSS 24 (IBM Corp). Classification and regression trees (CART) were used to identify the relative importance of environmental and socio-demographic variables of the DF clustering. This analysis was done using the rpart packages of $\mathrm{R}$ (Therneau et al., 2019). Nine socio-demographic factors at the village level, i.e. mean age of patients; gender; drinking water source; main occupation; proportion of households in the slum area; population density; road density; total number of doctors; and doctors per 1000 population were incorporated into the model using the class method of the rpart function. The sample consisted of 60 villages from two classes (HH and LL) based on the clustering analysis.

\section{Results}

\section{Descriptive statistics}

A total of 265,225 DF cases were reported in Jakarta in the period 2007-2018. The proportion of DF cases among those aged 24 years or more (at the time of infection) was 94,598 (35.7\%), which is a significantly higher number compared other age groups; the number of males in this group was slightly higher than the females ( $\mathrm{n}=139,911 ; 52.8 \%)$ (Table 1). Overall, the incidence of DF cases per year was reduced by approximately $80 \%$ from $325.5 / 100,000$ people in 2007 to $71.67 / 100,000$ people in 2018 . However, the annual incidence of DF fluctuated over the study years with the highest incidence observed in 2016 (424.06/100.000 people) (Table 1).

\section{Temporal pattern of dengue fever incidence}

The variability of monthly incidence was evident (Figure 1). Further, the boxplot chart shows that the monthly mean incidence was relatively higher in January to May, with the highest and lowest means observed in April and October, respectively (Figure 2). Seasonal decomposition confirmed the fluctuated trend and strong seasonality in the DF incidence (Figure 3).

Table 1. Summary statistics of notified dengue cases in Jakarta, Indonesia 2007-2018.

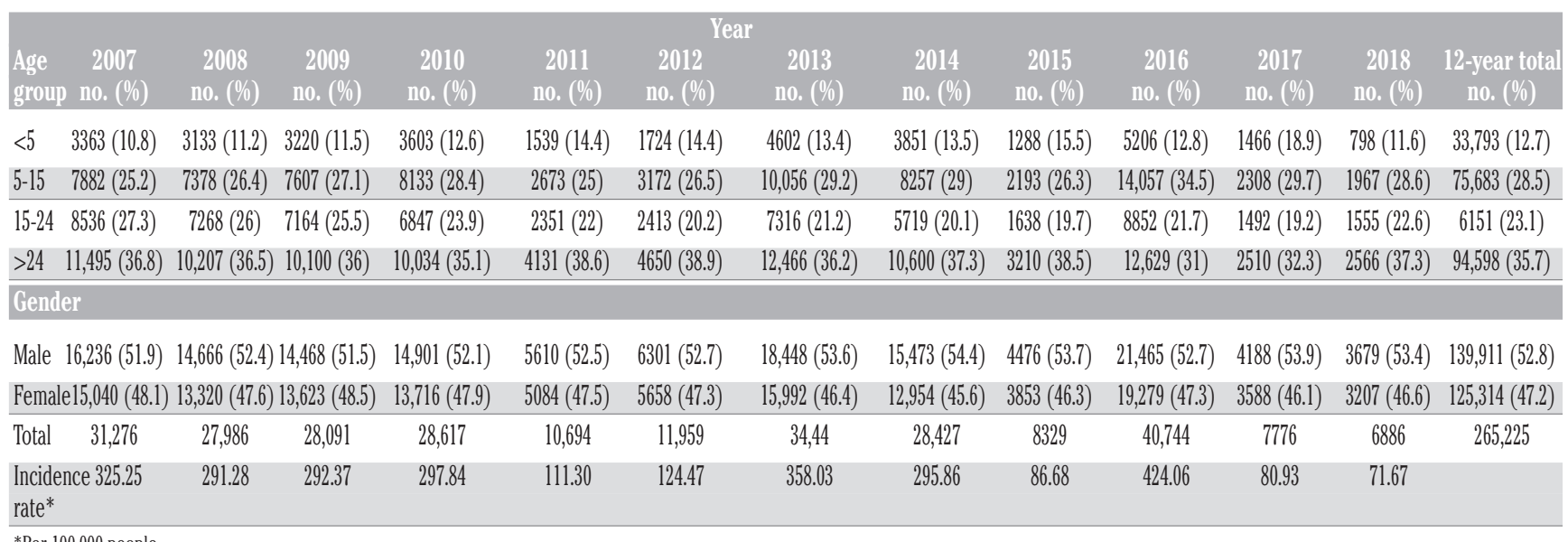

*Per 100,000 people. 


\section{Relationship between dengue fever incidence and climate}

Spearman's correlation analysis showed significant positive correlation between DF incidence with precipitation $(r=0.254$, $\mathrm{P}<0.01)$ and humidity $(r=0.340, \mathrm{P}<0.01)$. Negative correlation was observed between DF incidence and DMI $(r=-0.459, \mathrm{P}<0.01)$ and

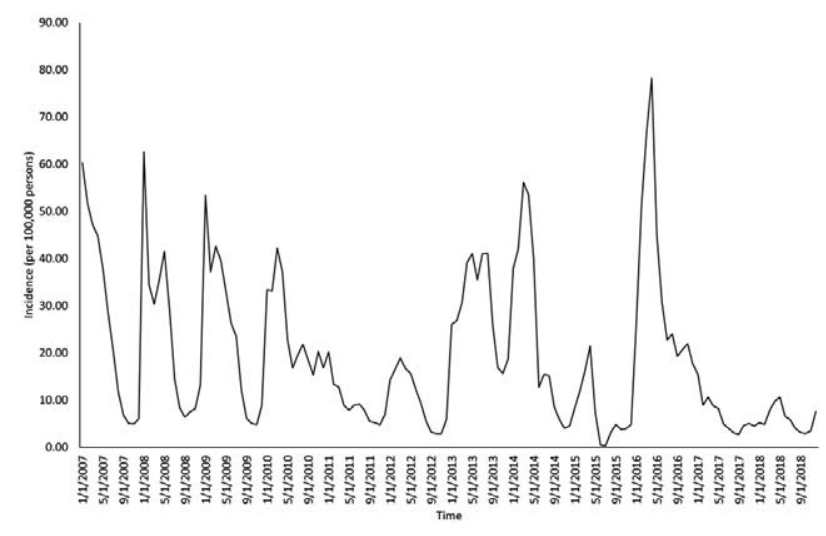

Figure 1. Incidence of dengue fever in Jakarta, Indonesia 20072018.
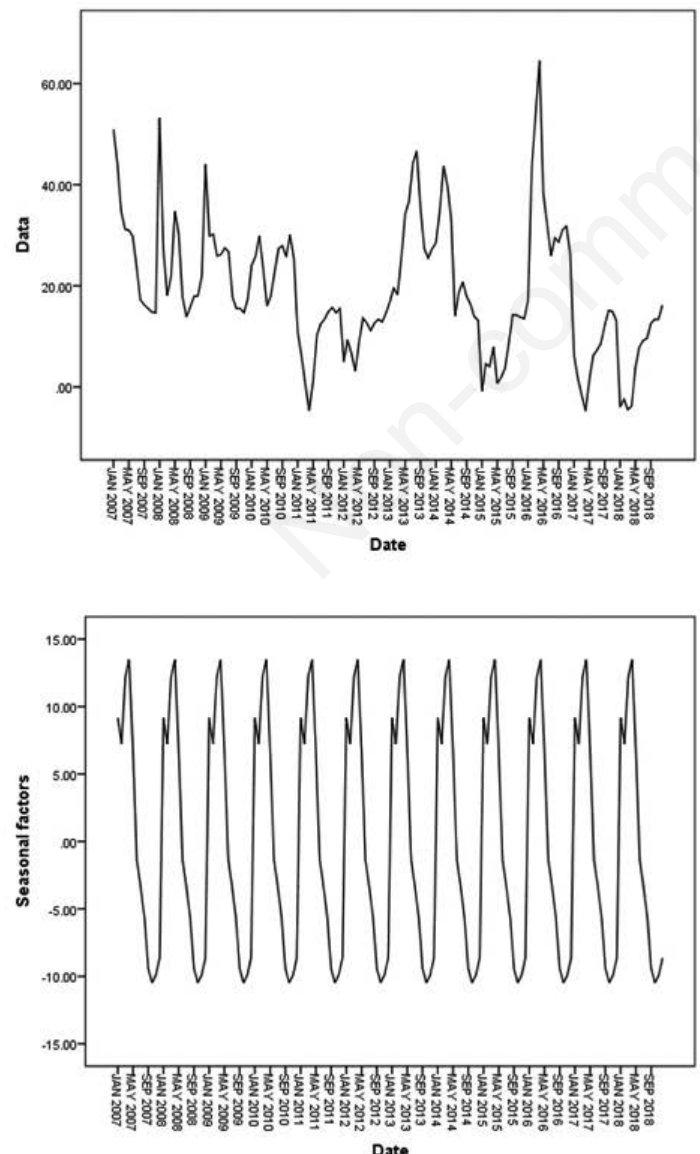

$\mathrm{T}_{\min }(r=-0.181, \mathrm{P}<0.05)$. The DMI was significantly negatively correlated with precipitation $(r=-0.309, \mathrm{P}<0.01)$ and humidity $(r=$ $-0.384, \mathrm{P}<0.01)$ but positively correlated with temperature. The correlations between DF incidence and Niño3.4, $\mathrm{T}_{\text {mean }}$ and $\mathrm{T}_{\max }$ were not statistically significant (Figure 4, Supplementary file Table S1).

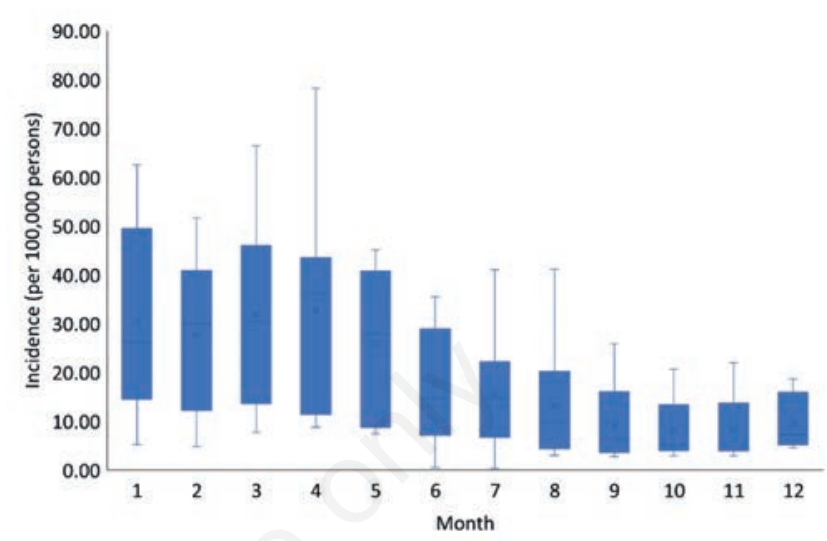

Figure 2. Monthly distribution of the incidence of dengue fever in Jakarta, Indonesia.
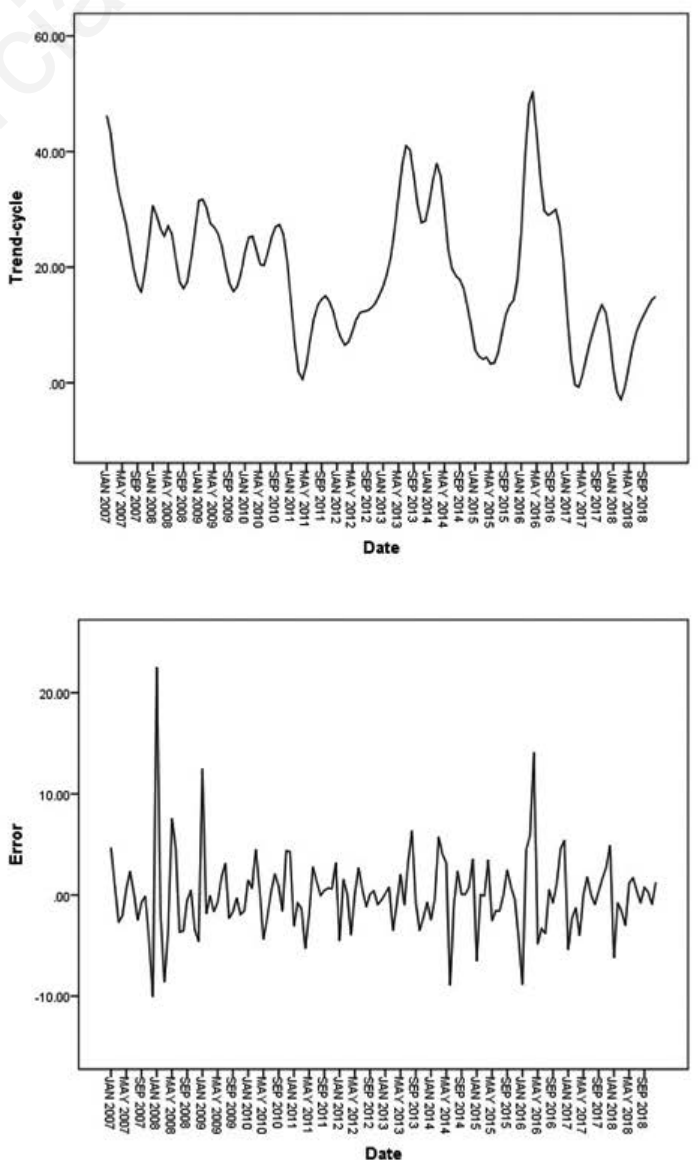

Figure 3. Decomposition of the dengue fever incidence in Jakarta, Indonesia. 


\section{Spatial distribution of dengue fever incidence}

The distribution of crude, cumulative incidence of DF was spatially different at the village level across the city, with a high incidence observed in certain villages including Setiabudi (1098/10,000 persons), West Kelapa Gading (1019/10,000 persons), Gambir (825/10,000 persons), East Kelapa Gading (772/10,000 persons) and Rawa Sari (676/10,000 persons) (Figure $5)$. In addition, the application of Moran's $I$ statistics showed the DF incidence during the period to be significantly clustered (Table 2 ), with the power of spatial clustering relatively stable over the whole period studied. Overall, over the period studied, the Local Moran's $I$ statistic identified $22 \mathrm{HH}$ clusters or hotspots including a population of 795,702 at risk. The analysis also identified $38 \mathrm{LL}$ clusters and spatial outliers (six HL clusters and six LH clusters). A detailed list of these clusters is given in the Supplementary file. The map shown in Figure 6 illustrates the annual dynamic of the distribution of DF clusters from 2007 to 2018. Hotspots were identified in Central, East and South Jakarta and some villages were consistently identified as hotspots over the period, including East Cempaka Putih (Central Jakarta), Kayu Putih (East Jakarta) and Sumur Batu (Central Jakarta). Meanwhile, it was evident that some hotspots emerged in the northwest and south Jakarta in the period 2016-2018. The number of $\mathrm{HH}$ villages increased by $50 \%$ during the period, from 21 in 2007 to 32 in 2018 . The population at risk ranged from 421,264 to $1,440,048$ (Table 3).

\section{Demographical and socio-ecological profiles}

The demographical and socio-ecological characteristics of hotspots and low risk clusters are given in Table 4. Compared to low risk clusters, the DF hotspots were characterised by a relatively higher number of cases (38.8\%) among people older than 24 years and further characterized by predominantly working in service industries, living and areas with less number of households in slum, a high ratio of doctor per 1000 people and a lower population density. Based on CART analysis, age (15.5\%) and occupation $(11.2 \%)$ were the most important variables determining the DF clustering (Table 5, Supplementary Figure S1).

Table 2. Annual spatial clustering estimated by Moran (1950) analysis.

\begin{tabular}{lll} 
Year & Moran's I & P-value \\
2007 & 0.314 & 0.001 \\
2008 & 0.258 & 0.001 \\
\hline 2009 & 0.324 & 0.001 \\
2010 & 0.298 & 0.001 \\
\hline 2011 & 0.258 & 0.001 \\
2012 & 0.144 & 0.001 \\
\hline 2013 & 0.397 & 0.001 \\
2014 & 0.358 & 0.001 \\
\hline 2015 & 0.354 & 0.001 \\
2016 & 0.345 & 0.001 \\
\hline 2017 & 0.345 & 0.001 \\
2018 & 0.326 & 0.001 \\
\hline $2007-2018$ & 0.294 & 0.001 \\
\hline
\end{tabular}

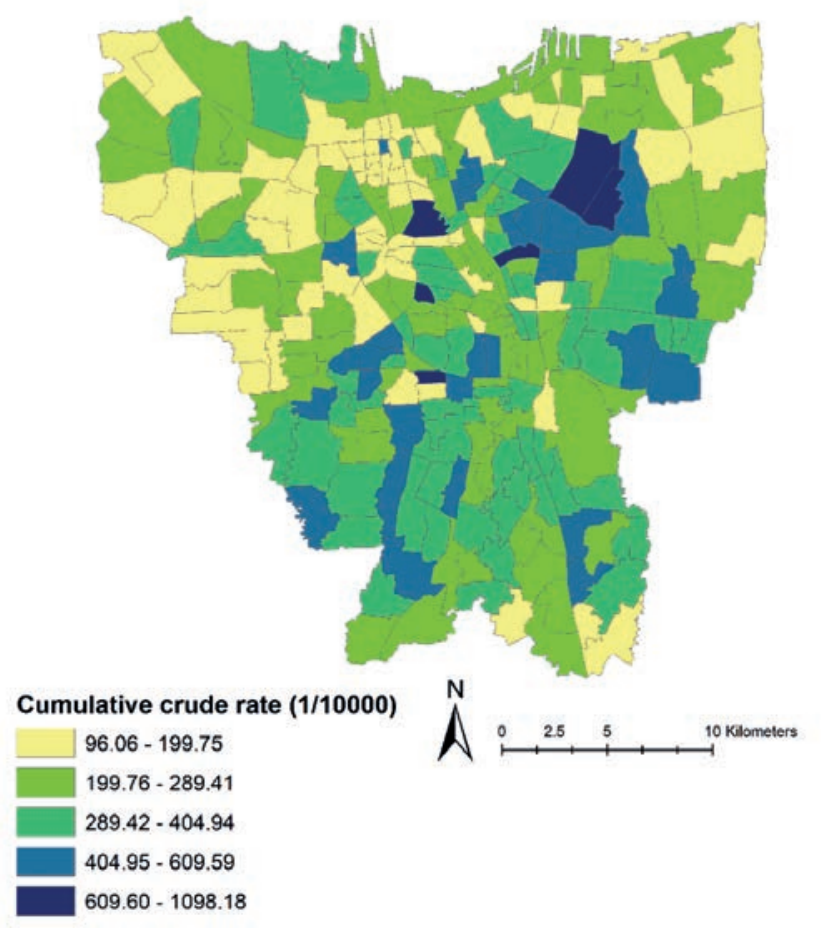

Figure 5. Cumulative crude incidence (per 10,000 population) of dengue fever at village-level in across Jakarta, Indonesia 20072018.
Figure 4. Spearman's correlation matrix for dengue fever (DF) incidence and climatic variables. RH, relative humidity; DMI, dipole mode index. 


\section{Discussion}

To best our knowledge, this study is the first attempt to explore the spatial heterogeneity of DF incidence and hotspots at the village level in Indonesia by examining correlations between incidence and climate variables based on a 12-year dataset. We found significant changes in the trends of the spatial DF incidence pattern and identified 22 hotspots across the city, some of which persisted over the whole study period. It was also noted that the DF high-risk clusters primarily included individuals over 24 years of age living in better, less populated surroundings. Our analysis showed that age and occupation were the main contributors to the clustering.

The DF long-term incidence trend fluctuated over the period studied with at least two major peaks (in 2014 and 2016), a pattern likely to be driven by climate variations. However, this association could not be fully shown as changes could also related to improved reporting, surveillance or changes on people's awareness towards DF. However, there was no significant change in the DF surveillance/reporting system in Jakarta or in other provinces in Indonesia during the period (Harapan et al., 2019a). On the other hand, the strong DF seasonality was obvious and this can be explained by its significant correlation with the seven climatic factors as evidenced in the present study. Our analysis suggests that the temporal pattern of DF incidence is positively correlated with the monthly variability of rainfall and humidity but negatively influenced by the minimum temperature and DMI. This finding is consistent with studies in other parts of Indonesia (Tosepu et al., 2018; Astuti et al., 2019) as well as other tropical cities such as Bangkok, Thailand (Polwiang, 2020) and Hanoi, Viet Nam (Thi Tuyet-Hanh, 2018).

We also attempted to further investigate the influence of the

Table 3. Descriptive statistics of dengue fever clusters as identified by local indicator spatial association in Jakarta, Indonesia $2007-2018$.

\begin{tabular}{|c|c|c|c|c|c|}
\hline Year & Cluster & Number of DF cases & Incidence per 10,000 people & Number of villages & Population at risk \\
\hline 2007 & $\begin{array}{l}\text { High-high } \\
\text { Low-low } \\
\text { Outliers (HL \& LH) }\end{array}$ & $\begin{array}{l}4726 \\
3879 \\
1132\end{array}$ & $\begin{array}{l}59.46 \\
17.50 \\
33.93\end{array}$ & $\begin{array}{l}21 \\
42 \\
11\end{array}$ & $\begin{array}{c}794,824 \\
2,215,947 \\
333,625\end{array}$ \\
\hline 2008 & $\begin{array}{l}\text { High-high } \\
\text { Low-low } \\
\text { Outliers (HL \& LH) }\end{array}$ & $\begin{array}{c}5939 \\
3275 \\
354\end{array}$ & $\begin{array}{l}52.26 \\
14.88 \\
21.92\end{array}$ & $\begin{array}{c}28 \\
41 \\
8\end{array}$ & $\begin{array}{c}1,136,477 \\
2,200,504 \\
161,494\end{array}$ \\
\hline 2009 & $\begin{array}{l}\text { High-high } \\
\text { Low-low } \\
\text { Outliers (HL \& LH) }\end{array}$ & $\begin{array}{c}4392 \\
1698 \\
684\end{array}$ & $\begin{array}{l}53.02 \\
10.43 \\
25.77\end{array}$ & $\begin{array}{l}24 \\
36 \\
10\end{array}$ & $\begin{array}{c}828,311 \\
1,628,411 \\
265,464\end{array}$ \\
\hline 2010 & $\begin{array}{l}\text { High-high } \\
\text { Low-low } \\
\text { Outliers (HL \& LH) }\end{array}$ & $\begin{array}{l}4065 \\
2729 \\
1038 \\
\end{array}$ & $\begin{array}{l}51.65 \\
18.42 \\
31.01\end{array}$ & $\begin{array}{l}23 \\
35 \\
11\end{array}$ & $\begin{array}{c}787,047 \\
1,481,362 \\
334,736\end{array}$ \\
\hline 2011 & $\begin{array}{l}\text { High-high } \\
\text { Low-low } \\
\text { Outliers (HL \& LH) }\end{array}$ & $\begin{array}{l}1675 \\
731 \\
278\end{array}$ & $\begin{array}{c}19.39 \\
6.47 \\
12.40\end{array}$ & $\begin{array}{c}22 \\
27 \\
7\end{array}$ & $\begin{array}{c}863,649 \\
1,129,593 \\
224,154\end{array}$ \\
\hline 2012 & $\begin{array}{l}\text { High-high } \\
\text { Low-low } \\
\text { Outliers (HL \& LH) }\end{array}$ & $\begin{array}{l}1188 \\
496 \\
292\end{array}$ & $\begin{array}{c}19.57 \\
7.71 \\
12.64\end{array}$ & $\begin{array}{l}15 \\
19 \\
8\end{array}$ & $\begin{array}{l}607,100 \\
643,563 \\
231,020\end{array}$ \\
\hline 2013 & $\begin{array}{l}\text { High-high } \\
\text { Low-low } \\
\text { Outliers (HL \& LH) }\end{array}$ & $\begin{array}{c}6835 \\
2192 \\
520\end{array}$ & $\begin{array}{l}72.75 \\
16.74 \\
37.90\end{array}$ & $\begin{array}{c}25 \\
38 \\
5\end{array}$ & $\begin{array}{c}939,508 \\
1,309,417 \\
137,198\end{array}$ \\
\hline 2014 & $\begin{array}{l}\text { High-high } \\
\text { Low-low } \\
\text { Outliers (HL \& LH) }\end{array}$ & $\begin{array}{c}3823 \\
2278 \\
589\end{array}$ & $\begin{array}{l}58.88 \\
16.31 \\
25.40\end{array}$ & $\begin{array}{c}19 \\
38 \\
8\end{array}$ & $\begin{array}{c}649,282 \\
1,396,885 \\
231,912\end{array}$ \\
\hline 2015 & $\begin{array}{l}\text { High-high } \\
\text { Low-low } \\
\text { Outliers (HL \& LH) }\end{array}$ & $\begin{array}{c}1475 \\
508 \\
64\end{array}$ & $\begin{array}{c}35.01 \\
4.10 \\
8.45\end{array}$ & $\begin{array}{c}10 \\
35 \\
3\end{array}$ & $\begin{array}{c}421,264 \\
1,238,131 \\
75,698\end{array}$ \\
\hline 2016 & $\begin{array}{l}\text { High-high } \\
\text { Low-low } \\
\text { Outliers (HL \& LH) }\end{array}$ & $\begin{array}{l}8771 \\
4107 \\
1046\end{array}$ & $\begin{array}{l}67.95 \\
24.97 \\
40.87\end{array}$ & $\begin{array}{l}33 \\
45 \\
12\end{array}$ & $\begin{array}{c}1,290,827 \\
1,645,097 \\
255,932\end{array}$ \\
\hline 2017 & $\begin{array}{l}\text { High-high } \\
\text { Low-low } \\
\text { Outliers (HL \& LH) }\end{array}$ & $\begin{array}{l}1813 \\
610 \\
215\end{array}$ & $\begin{array}{l}12.59 \\
4.18 \\
8.00\end{array}$ & $\begin{array}{l}31 \\
44 \\
10\end{array}$ & $\begin{array}{c}1,440,048 \\
1,458,553 \\
268,793\end{array}$ \\
\hline 2018 & $\begin{array}{l}\text { High-high } \\
\text { Low-low } \\
\text { Outliers (HL \& LH) }\end{array}$ & $\begin{array}{l}1153 \\
465 \\
192\end{array}$ & $\begin{array}{c}11.59 \\
3.81 \\
6.89\end{array}$ & $\begin{array}{l}32 \\
31 \\
10\end{array}$ & $\begin{array}{c}995,018 \\
1,218,951 \\
278,769\end{array}$ \\
\hline
\end{tabular}

DF, dengue fever; HL, high-low; LH, low-high. 
Table 4. Sociodemographic and ecological characteristics of dengue fever clusters in Jakarta, Indonesia 2007-2018.

\begin{tabular}{|c|c|c|c|c|}
\hline Characteristics & $\begin{array}{r}\text { Spat } \\
\text { HH }(n=22)\end{array}$ & LL $(n=38)$ & $t / \chi^{2} / \mathrm{U}$ & P-value \\
\hline Mean age (SD) (years) & $22.42(16.36)$ & $21.02(15.62)$ & $t=10.848$ & $<0.001$ \\
\hline $\begin{array}{l}\text { Age group (\%) } \\
\quad<5 \\
\quad 5-15 \\
\quad 15-24 \\
>24\end{array}$ & $\begin{array}{l}11.8 \\
25.8 \\
23.7 \\
38.8\end{array}$ & $\begin{array}{l}12.4 \\
28.6 \\
23.6 \\
35.4\end{array}$ & $\chi^{2}=95.79$ & $<0.001$ \\
\hline $\begin{array}{l}\text { Sex (\%) } \\
\text { Male } \\
\text { Female }\end{array}$ & $\begin{array}{l}52.2 \\
47.8\end{array}$ & $\begin{array}{l}52.2 \\
47.8\end{array}$ & $\chi^{2}=0.013$ & 0.908 \\
\hline $\begin{array}{l}\text { Village characteristics } \\
\text { Main occupation } \\
\text { Manufacturing } \\
\text { Trade/retail } \\
\text { Transportation and communication } \\
\text { Service }\end{array}$ & $\begin{array}{c}- \\
- \\
7(31.8) \\
15(68.2)\end{array}$ & $\begin{array}{c}11(28.95) \\
- \\
24(63.15) \\
3(7.90)\end{array}$ & $\chi^{2}=25.89$ & $<0.001$ \\
\hline $\begin{array}{l}\text { Source of drinking water } \\
\text { Retail/refill } \\
\text { Metered water } \\
\text { Borehole/pump }\end{array}$ & $\begin{array}{l}16(72.7) \\
5(22.7) \\
1(4.6)\end{array}$ & $\begin{array}{l}18(47.36) \\
15(39.48) \\
5(13.16)\end{array}$ & $\chi^{2}=4.80$ & 0.187 \\
\hline $\begin{array}{l}\text { Mean number of slum households } \\
\text { Mean road density }\left(\mathrm{km} \text { per } \mathrm{km}^{2}\right) \\
\text { Mean population density }\left(\text { per } \mathrm{km}^{2}\right) \\
\text { Mean doctor per } 1000 \text { people } \\
\text { Mean number of doctors per village }\end{array}$ & $\begin{array}{c}469 \\
17.57 \\
16,109 \\
0.32 \\
9\end{array}$ & $\begin{array}{c}1,402 \\
14.45 \\
40,638 \\
0.18 \\
7\end{array}$ & $\begin{array}{l}U=551.00 \\
U=307.00 \\
U=631.00 \\
U=271.00 \\
U=327.50\end{array}$ & $\begin{array}{l}0.038 \\
0.089 \\
0.001 \\
0.024 \\
0.164\end{array}$ \\
\hline
\end{tabular}

HH, high-high; LL, low-low; SD, standard deviation.

regional climate on the major outbreaks in 2014 and 2016. Although we found no significant correlation between DF incidence and Niño3.4 but we did note that the incidence of DF these years was negatively correlated with DMI. The positive correlation observed between DMI and the DF incidence might have triggered an increase in DF incidence in 2014 and 2016 after a 5-7 months lag period (Supplementary file Figure S2). Indeed, associations between IOD/DMI and DF incidence have also been reported in Bangladesh (Banu et al., 2015) and Pakistan (Atique et al., 2016) a positive IOD/DMI significantly multiplies the monsoon rainfall over the Indian region but in Indonesia the precipitation rate is reduced (Ashok et al., 2004; Hashizume et al., 2009). A combination between water shortage due to drought (which drives people to put out more containers to collect water) followed by increased rainfall (2-3 months before) may likely have driven the outbreak in 2016 (Supplementary file Figure S2).

The present study found clear evidence of geographical variation in incidence of DF at the village level in with a high incidence observed in central and east Jakarta. Central Jakarta is a highly populated area and it is the center of economic and business activities. The probability of human and vectors contact is likely to be influenced by the population/settlement density; the risk of being infected is likely to be higher in areas with more people (Hasanah and Susanna, 2019). The results in eastern Jakarta, on the other hand, could have primarily been caused by poor sanitation. Based on a recent environmental risk survey in this area, $72.8 \%$ of households showed moderate risk of DF transmission (Prasetyowati and Ginanjar, 2017). The spatial variation in risk, however, may also be partly explained by the variation in socio-ecological conditions, the effects of interventions (e.g., vector control), entomological characteristics (e.g., breeding sites, density and resistance) as well
Table 5. The overall importance of variables on the clustering of dengue fever based on the classification and regression trees model.

\begin{tabular}{lc} 
Variable & Overall \\
Mean age (in years) & 15.5 \\
Doctor per 1000 & 3.9 \\
\hline Source of drinking (\%) & 1.8 \\
Household slum (\%) & 6.5 \\
\hline Main occupation (\%) & 11.2 \\
Population density & 9.2 \\
\hline Road density & 1.8 \\
Sex & 0.0 \\
\hline Sum of doctor & 0.0
\end{tabular}

as immunity. We did not include meteorological factors (e.g. rainfall, temperature and humidity) in the comparative analysis since the meteorological variation at the village level was not evident. However, further exploration is important to understand the role of such societal and ecological on the spatial heterogeneity in risk of DF in Jakarta. Moreover, population-based studies are required to better understand the variation in risk factors at the various levels (individual, household and community). In addition, seroprevalence studies may be needed to understand the heterogeneity in the transmission dynamic.

The dynamic variation of the DF hotspots varied over years, may indicate changes in risk factors at the local level. In our study, DF high-risk clusters were characterized by a higher number of cases in people older than 24 years, which might be explained by 

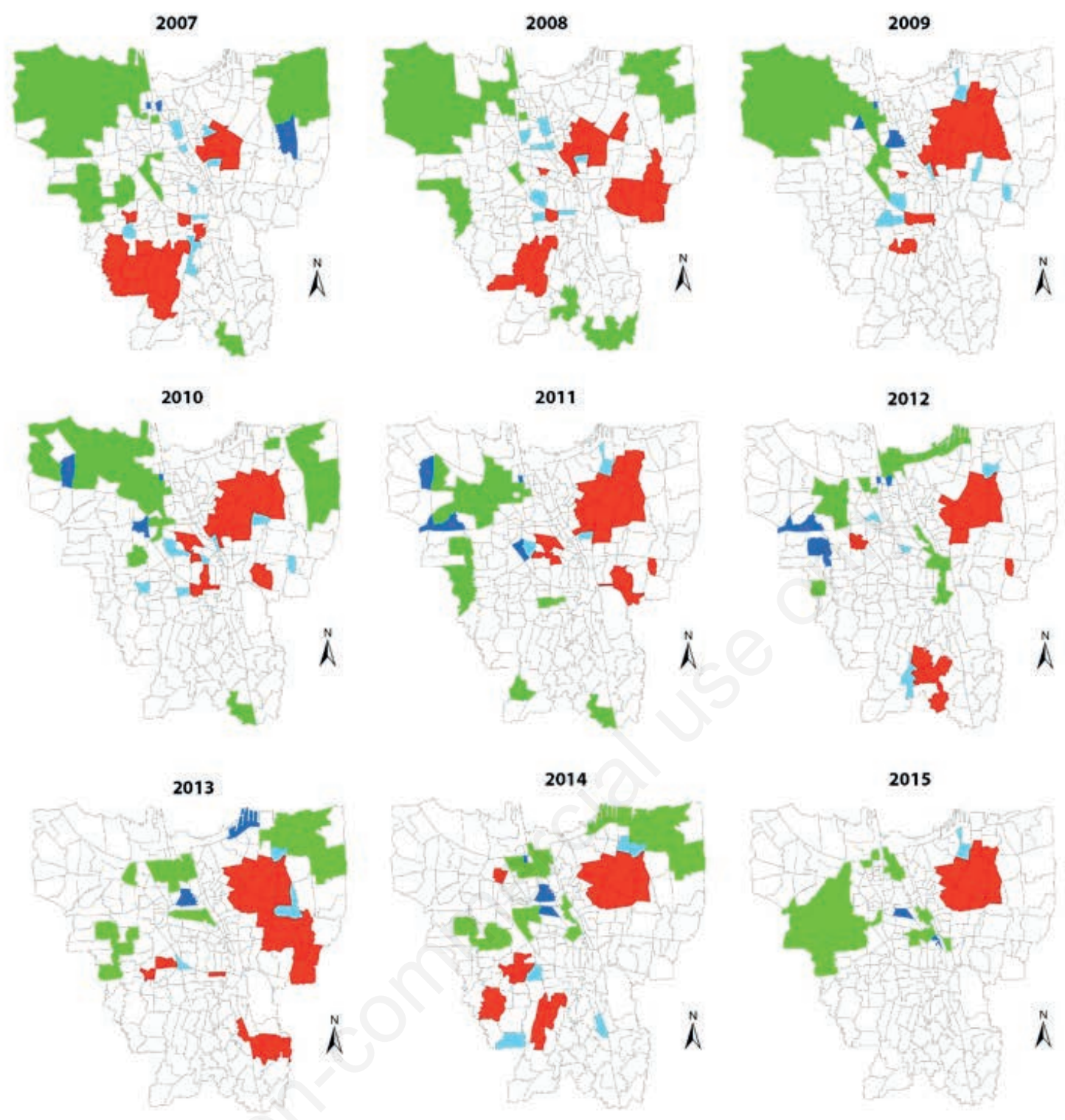

2014
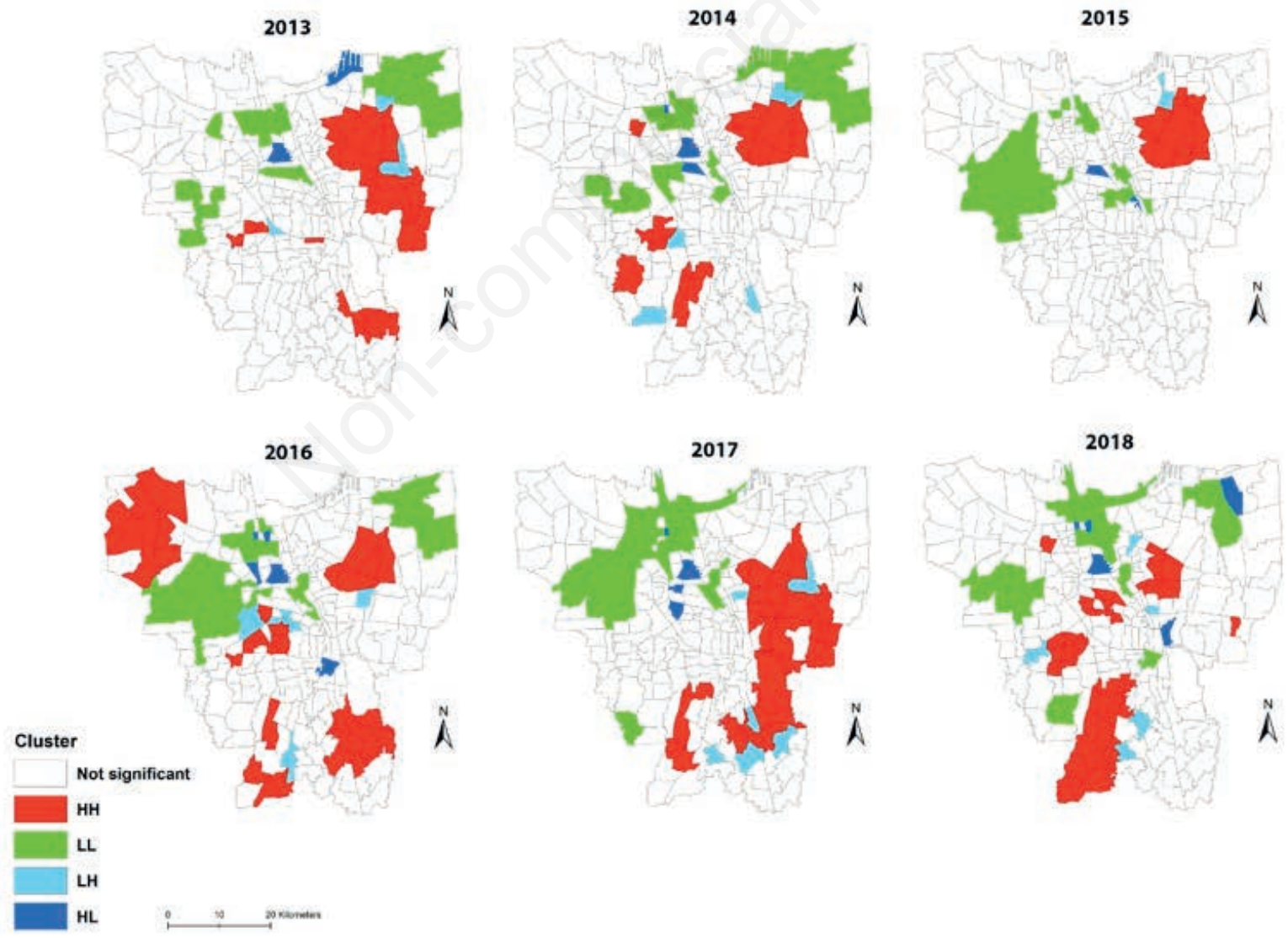

Figure 6. Spatial clusters for dengue fever in Jakarta during 2007 to 2018 as determined by local indicator spatial association analysis. 
higher levels of mobility of this population group as it consists of people engaged in productive work. Mobility is a known potential driver associated with pathogens transmission (Pybus et al., 2015; Zhu et al., 2019; Santos et al., 2019). In this study, we used road density as a proxy for mobility. While it is not statistically significantly different, the mean of the road density in high risk clusters was relatively higher than in the low-risk clusters. This finding is consistent with study in China (Qi et al., 2015) which found that higher road density is associated with an increased DF risk. In addition, our study found that DF hotspots were common in areas where most people are engaged in service industries compared. We therefore identified age and occupation as the important predictors of clustering.

This study found intriguing evidence that high risk DF areas (e.g., Kayu Putih, West Cempaka Putih) have a lower mean population density than those in the low-risk areas. Further, the average number of households in slum was much lower here than in the low-risk clusters. This is inconsistent with the many previous studies showing a positive correlation between DF risk and population density (Schmidt et al., 2011; Qi et al., 2015; Harapan et al., 2020) and poor socioeconomic conditions (Kikuti et al., 2015; Aswi et al., 2018). Our findings suggest that high DF risk not merely affect impoverished communities but also wealthy populations. It is important to note that inhabitants living in Kayu Putih (a sub-district in Pulo Gadung) have a relatively higher socioeconomic level compared to the surrounding sub-districts (data not shown) and to living in a well-maintained residential area. This finding may be closely linked with environmental and behavioral aspect, especially with regard to how people manage or store water and their yards. In addition, the mere presence of outdoor water bodies (e.g., pools and canals) has potential as breeding sites for the mosquitoes (Machault et al., 2014). In fact, interventions (e.g., routine vector control and monitoring) could not be effectively implemented in this neighborhood due to limited access given by the residents. A strong partnership between local health authorities and stakeholders (e.g., local community leaders, property management, private sectors) would be needed to change this situation. In addition, frequent flooding as a result of poor drainage system especially during rainy seasons, could be an environmental driver that maintains the risk of DF. These findings provide meaningful information for determining locations or areas where interventions and resources (e.g., awareness campaigns, vector monitoring, etc.) are needed the most. According to our findings, we recommend that area-specific interventions may be needed, accounting for local socio-ecological contexts of the village. Additionally, this study demonstrated that spatial analytical tools could be applied or integrated in the existing surveillance system to provide evidence in decision making processes (e.g., designing and evaluating intervention).

In this study, we also found that the high-risk clusters had a higher ratio of doctor per 1000 people compared to low-risk clusters. This is probably due to more precise reporting. The more available health services, the better the contact with infected patients leading to diagnosis and treatment. This is accordance with findings reported by Watts et al. (2020) in the Unites States and Mexico.

This study has several limitations. First, the present analysis was based on passive surveillance data with its potential bias of underreporting as many infected people do not report or present to health facilities if not severely ill. Second, the variation in DF incidence at the village scale may likely occur due to the heterogeneity of socio-ecological factors (e.g., disease awareness and behavior, mobility and vector density) (Prasetyowati and Ginanjar, 2017; Ren et al., 2017; Chen et al., 2019; Harapan et al., 2019a; Desjardins et al., 2020). However, such data were not available at the village level so that we could not include them the analysis. Despite the limitations, the study has provided important evidence and new approaches in identifying hotspots of DF in Jakarta, which could help improve existing surveillance activities. In the future, population-based epidemiological investigations should acquire a better understanding on DF epidemiology in Jakarta.

The spatial epidemiological approaches used in this study can be utilized and be integrated into the existing surveillance system to monitor and identify areas where intervention is needed at most. Further, understanding the role of the climate on DF distribution could help determine when interventions are needed. For instance, vector control and health promotion campaigns should be prioritised in the identified high-risk locations and certain populations just before the raining season which could be much more efficient and effective.

\section{Conclusions}

Our analysis identified a correlation between the DF incidence and local weather (precipitation, humidity, temperature) and regional climate variables, such as the DMI and Niño3.4. confirming that DF seasonality in Jakarta is driven by climatic components. Our study reveals that the DF hotspots remained at particular parts of the city of Jakarta during the period studied. Persistent hotpots are strong indications for the need of enhanced and focal intervention strategies (e.g., community-based vector control, campaigns).

\section{References}

Anselin L, 1995. Local indicators of spatial association - LISA. Geogr Anal 27:93-115.

Ashok K, Guan Z, Saji NH, Yamagata T, 2004. Individual and Combined Influences of ENSO and the Indian Ocean Dipole on the Indian Summer Monsoon. J. Climate 17:3141-55.

Astuti EP, Dhewantara PW, Prasetyowati H, Ipa M, Herawati C, Hendrayana K, 2019. Paediatric dengue infection in Cirebon, Indonesia: a temporal and spatial analysis of notified dengue incidence to inform surveillance. Parasit Vectors 12:186.

Aswi A, Cramb S, Moraga P, Mengersen K. Bayesian spatial and spatio-temporal approaches to modelling dengue fever: a systematic review. Epidemiol Infect 2018;147:1-14.

Atique S, Abdul SS, Hsu CY, Chuang TW, 2016. Meteorological influences on dengue transmission in Pakistan. Asian Pac J Trop Med 9:954-61.

Banu S, Guo Y, Hu W, Dale P, Mackenzie JS, Mengersen K, Tong S, 2015. Impacts of El Niño Southern Oscillation and Indian Ocean Dipole on dengue incidence in Bangladesh. Sci Rep 5:16105.

Bhatt S, Gething PW, Brady OJ, Messina JP, Farlow AW, Moyes CL, Drake JM, Brownstein JS, Hoen AG, Sankoh O, Myers MF, George DB, Jaenisch T, Wint GR, Simmons CP, Scott TW, Farrar JJ, Hay SI, 2013. The global distribution and burden of dengue. Nature 496:504-7.

Biswal S, Reynales H, Saez-Llorens X, Lopez P, Borja-Tabora C, 
Kosalaraksa P, Sirivichayakul C, Watanaveeradej V, Rivera L, Espinoza F, Fernando L, Dietze R, Luz K, Venâncio da Cunha R, Jimeno J, López-Medina E, Borkowski A, Brose M, Rauscher M, LeFevre I, Bizjajeva S, Bravo L, Wallace D; TIDES Study Group, 2019. Efficacy of a tetravalent dengue vaccine in healthy children and adolescents. N Engl J Med 381:2009-19.

Carvalho S, Magalhães MAFM, Medronho RA, 2017. Analysis of the spatial distribution of dengue cases in the city of Rio de Janeiro, 2011 and 2012. Rev Saude Publica 51:79.

Chen Y, Zhao Z, Li Z, Li W, Li Z, Guo R, Yuan Z, 2019. Spatiotemporal transmission patterns and determinants of dengue fever: a case study of Guangzhou, China. Int J Environ Res Public Health 16:2486.

Cleveland RB, Cleveland WS, McRae JE, Terpenning I, 1990. STL: a seasonal-trend decomposition. J Off Stat 6:3-73.

Desjardins MR, Casas I, Victoria AM, Carbonell D, Dávalos DM, Delmelle EM, 2020. Knowledge, attitudes, and practices regarding dengue, chikungunya, and Zika in Cali, Colombia. Health Place 63:102339.

Diptyanusa A, Lazuardi L, Jatmiko RH, 2020. Implementation of geographical information systems for the study of diseases caused by vector-borne arboviruses in Southeast Asia: A review based on the publication record. Geospat Health 15:862.

Fletcher-Lartey SM, Caprarelli G, 2016. Application of GIS technology in public health: successes and challenges. Parasitology 143:401-15.

Fuentes-Vallejo M, 2017. Space and space-time distributions of dengue in a hyper-endemic urban space: the case of Girardot, Colombia. BMC Infect Dis 17:512.

Gimenez JO, Alvarez CN, Almirón WR, Stein M, 2020. Meteorological variables associated with the temporal oviposition rate of Aedes aegypti (Diptera: Culicidae) in Resistencia city, Chaco province, Northeastern Argentina. Acta Trop 212:105678.

Hamid PH, Prastowo J, Ghiffari A, Taubert A, Hermosilla C, 2017. Aedes aegypti resistance development to commonly used insecticides in Jakarta, Indonesia. PLoS One 12:e0189680.

Harapan H, Michie A, Yohan B, Shu PY, Mudatsir M, Sasmono RT, Imrie A, 2019a. Dengue viruses circulating in Indonesia: A systematic review and phylogenetic analysis of data from five decades. Rev Med Virol 29:e2037.

Harapan H, Michie A, Mudatsir M, Sasmono RT, Imrie A, 2019b. Epidemiology of dengue hemorrhagic fever in Indonesia: analysis of five decades data from the National Disease Surveillance. BMC Res Notes 12:350.

Harapan H, Michie A, Sasmono RT, Imrie A, 2020. Dengue: a minireview. Viruses 12:829.

Hasanah, Susanna D, 2019. Weather implication for dengue fever in Jakarta, Indonesia 2008-2016. KnE Life Sci 4:184.

Hashizume M, Terao T, Minakawa N, 2009. The Indian Ocean Dipole and malaria risk in the highlands of western Kenya. Proc Natl Acad Sci U S A 106:1857-62.

Karyanti MR, Uiterwaal CS, Kusriastuti R, Hadinegoro SR, Rovers MM, Heesterbeek H, Hoes AW, Bruijning-Verhagen P, 2014. The changing incidence of dengue haemorrhagic fever in Indonesia: a 45-year registry-based analysis. BMC Infect Dis 14:1-7.

Kikuti M, Cunha GM, Paploski IA, Kasper AM, Silva MM, Tavares AS, Cruz JS, Queiroz TL, Rodrigues MS, Santana PM,
Lima HCAV, Calcagno J, Takahashi D, Gonçalves AHO, Araújo JMG, Gauthier K, Diuk-Wasser MA, Kitron U, Ko AI, Reis MG, Ribeiro GS, 2015. Spatial distribution of dengue in a Brazilian urban slum setting: role of socioeconomic gradient in disease risk. PLoS Negl Trop Dis 9:e0003937.

Lestari CSW, Yohan B, Yunita A, Meutiawati F, Hayati RF, Trimarsanto H, Sasmono RT, 2017. Phylogenetic and evolutionary analyses of dengue viruses isolated in Jakarta, Indonesia. Virus Genes 53:778-88.

Li Q, Cao W, Ren H, Ji Z, Jiang H, 2018. Spatiotemporal responses of dengue fever transmission to the road network in an urban area. Acta Trop 183:8-13.

Machault V, Yébakima A, Etienne M, Vignolles C, Palany P, Tourre YM, Guérécheau M, Lacaux, JP, 2014. Mapping Entomological Dengue Risk Levels in Martinique Using HighResolution Remote-Sensing Environmental Data. ISPRS Int. J Geo-Inf 3:1352-71.

Ministry of Health of Indonesia, 2018. 2018 Indonesia health profile. Ministry of Health, Jakarta, Indonesia.

Moran PAP, 1950. Notes on continuous stochastic phenomena. Biometrika 37:17-23.

Morin CW, Comrie AC, Ernst K, 2013. Climate and dengue transmission: evidence and implications. Environ Health Perspect 121:1264-72.

Oliveira MA, Ribeiro H, Castillo-Salgado C, 2013. Geospatial analysis applied to epidemiological studies of dengue: a systematic review. Rev Bras Epidemiol 16:907-17.

Polwiang S, 2020. The time series seasonal patterns of dengue fever and associated weather variables in Bangkok (20032017). BMC Infect Dis 12:208.

Prasetyowati H, Ginanjar A, 2017. Maya Indeks dan Kepadatan Larva Aedes aegypti di Daerah Endemis DBD Jakarta Timur. Vektora 9:43.

Pybus OG, Tatem AJ, Lemey P, 2015. Virus evolution and transmission in an ever more connected world. Proc R Soc B 282:20142878

Qi X, Wang Y, Li Y, Meng Y, Chen Q, Ma J, Gao GF, 2015. The effects of socioeconomic and environmental factors on the incidence of dengue fever in the Pearl River Delta, China, 2013. PLoS Negl Trop Dis 9:e0004159.

Ren H, Zheng L, Li Q, Yuan W, Lu L, 2017. Exploring determinants of spatial variations in the dengue fever epidemic using geographically weighted regression model: a case study in the joint Guangzhou-Foshan Area, China, 2014. Int J Environ Res Public Health 14:1518.

Santos J, Honorio NA, Nobre AA, 2019. Definition of persistent areas with increased dengue risk by detecting clusters in populations with differing mobility and immunity in Rio de Janeiro, Brazil. Cad Saude Publica 35:e00248118.

Schmidt WP, Suzuki M, Thiem VD, White RG, Tsuzuki A, Yoshida LM, Yanai H, Haque U, Tho le H, Anh DD, Ariyoshi K, 2011. Population density, water supply, and the risk of dengue fever in Vietnam: cohort study and spatial analysis. PLoS Med 8:e1001082.

Seidahmed OM, Eltahir EA, 2016. A sequence of flushing and drying of breeding habitats of Aedes aegypti (L.) Prior to the low dengue season in Singapore. PLoS Negl Trop Dis 10:e004842.

Shepard DS, Undurraga EA, Halasa YA, Stanaway JD, 2016. The global economic burden of dengue: a systematic analysis. Lancet Infect Dis 16:935-41. 
Sumarmo T, 1987. Dengue haemorrhagic fever in Indonesia. Southeast Asian J Trop Med Public Health 18:269-74.

Therneau T, Atkinson B, Ripley B, 2019. Package 'rpart' [Online]. Available from: https://cran.r-project.org/web/packages/rpart/ index.html

Thi Tuyet-Hanh T, Nhat Cam N, Thi Thanh Huong L, Khanh Long T, Mai Kien T, Thi Kim Hanh D, Huu Quyen N, Nu Quy Linh T, Rocklöv J, Quam M, Van Minh H, 2018. Climate Variability and Dengue Hemorrhagic Fever in Hanoi, Viet Nam, During 2008 to 2015. Asia Pac J Public Health 30:532-41.

Tosepu R, Tantrakarnapa K, Nakhapakorn K, Worakhunpiset S, 2018. Climate variability and dengue hemorrhagic fever in Southeast Sulawesi Province, Indonesia. Environ Sci Pollut Res 25:14944-52.

Watts MJ, Kotsila P, Mortyn PG, Sarto I Monteys V, Urzi Brancati C, 2020. Influence of socio-economic, demographic and climate factors on the regional distribution of dengue in the United States and Mexico. Int J Health Geogr 19:44.
WHO (World Health Organization), 2011. Comprehensive guideline for prevention and control of dengue and dengue haemorrhagic fever. World Health Organization, Geneva, Switzerland.

Xu Z, Bambrick H, Yakob L, Devine G, Lu J, Frentiu FD, Yang W, Williams G, Hu W, 2019. Spatiotemporal patterns and climatic drivers of severe dengue in Thailand. Sci Total Environ 656:889-901.

Zambrano LI, Rodriguez E, Espinoza-Salvado IA, FuentesBarahona IC, Lyra de Oliveira T, Luciano da Veiga G, Cláudio da Silva J, Valle-Reconco JA, Rodríguez-Morales AJ, 2019. Spatial distribution of dengue in Honduras during 2016-2019 using a geographic information systems (GIS)-Dengue epidemic implications for public health and travel medicine. Travel Med Infect Dis 2019:101517.

Zhu G, Liu T, Xiao J, Zhang B, Song T, Zhang Y, Lin L, Peng Z, Deng A, Ma W, Hao Y, 2019. Effects of human mobility, temperature and mosquito control on the spatiotemporal transmission of dengue. Sci Total Environ 651:969-78. 